\title{
Inheritance of Stringless Pod in Pisum sativum L.
}

\author{
Rebecca J. McGee' and James R. Baggett ${ }^{2}$ \\ Department of Horticulture, 2042 Cordley Hall, Oregon State University, Corvallis, \\ OR 97331-2911
}

\begin{abstract}
Additional index words. edible pod peas, snap peas, vegetable breeding
Abstract. In crosses between stringless and stringy podded pea cultivars, all plants of the $F_{1}$ and backcross to the stringy parent had stringy pods. $F_{2}$ ratios varied widely among crosses, and populations always had more stringy plants than expected, based on a single locus. The ratio of nonsegregating (stringy) : segregating $F_{3}$ families derived from stringy $F_{2}$ plants fit a single-gene hypothesis in half of the crosses. Backcrosses of $F_{1}$ to the stringless parent fit the expected 1:1 ratio when the pollen parent was stringless, but the reciprocal backcrosses showed a deficiency of stringless plants, suggesting that poor competitive ability of pollen bearing the stringless factor was the reason for deficiencies of stringless plants. It is concluded that stringlessness is controlled by a single recessive gene for which the designation sin-2 is proposed. A reduction in pod size, plant height, and number of wrinkled seed segregates was associated with stringlessness.
\end{abstract}

Edible pod peas differ from green shell and dry edible types in that they lack "parchment," the normal fibrous layer composed of highly lignified sclerenchyma cells in the inner pod wall. The edible condition results from the action of one or both of two independent recessive genes, $p$ and $v$. Either gene present in the homozygous condition greatly reduces parchment, while pods of plants homozygous for both $p$ and $v$ are considered parchment-free (White, 1917). Typical, thin-walled edible pod peas (snow peas), also known as Chinese peas and Oriental peas, have increased in commercial importance during the past decade. Since 1979, a form of edible pod pea with thick pod walls has become commercially important with the introduction of the cultivar Sugar Snap by C. Lamborn of the Gallatin Valley Seed Co. (Thorndyke, 1983). In this type, formerly called "butter peas," but currently termed "snap peas," the recessive gene $n$ conditions thick pod walls and a narrower pod that becomes round in cross section with maturity and tends to be curved (Wehner and Gritton, 1981; Wellensiek, 1925).

Snow peas and snap peas, as well as parchmented green shell and dry edible types, are normally characterized by a prominent "string" that is present in, both pod sutures but is especially strong in the ventral suture. The string, comprised of strong, lignified sclerenchymous fibers, must be removed from both snow pea and snap pea pods before they are eaten, except when they are very young. This need is especially disadvantageous in snap peas, which are usually eaten quite mature. The stringy character initially prevented the commercial processing of these peas, even though they are adapted to machine harvest.

Lamprecht (1938) described a spontaneous mutation in which the fibrous string along the sutures and adjacent to the lateral carpellary vascular bundles is absent, i.e., the pods are stringless. He named this recessive gene $\sin$, but it has apparently been lost. Wellensiek (1971) recovered another stringless mutant in the $\mathrm{M}_{2}$ of ethylenimine-treated 'Dominant'. In a brief note, he mentioned the mutant and that its expression depended on high temperature $(\geq 21 \mathrm{C})$. He did not include inheritance

\footnotetext{
Received for publication 6 May 1991. Accepted for publication 28 Feb. 1992. Oregon Agricultural Experiment Station Technical Paper no. 9600. The assistance and advice of Calvin Lamborn, Rogers-NK Seed Co., and the late G.A. Marx of the New York Agricultural Experiment Station are gratefully acknowledged. The cost of publishing this paper was defrayed in part by the payment of page charges. Under postal regulations, this paper therefore must be hereby marked advertisement solely to indicate this fact.

'Formerly Graduate Research Assistant. Current address: The Pillsbury Co., 1201 North Fourth Street, Le Sueur, MN 56058.

${ }^{2}$ Professor of Horticulture.
}

data or mention problems in breeding, other than temperature sensitivity. Wellensiek's material was subsequently used in the development of stringless snow pea 'Nofila' (NOF) by Nunhems Seed Co. (Haelen, Netherlands), and a series of snap peas, typified by 'Sugar Daddy' (SD), by the Gallatin Valley Seed Co. (Twin Falls, Idaho). We have found the stringless character difficult to use in breeding because the number of stringless plants recovered in segregating generations has been fewer than expected for a presumed monogenic character and because it is difficult to recover vigorous stringless plants with wrinkled seeds.

The purpose of this study was to determine the inheritance of Wellensiek's stringless pod character in peas and investigate its association with pod size, plant vigor, and seed type.

\section{Materials and Methods}

The three stringless parents used in this study were all developed from Wellensiek's (1971) material. L169, a breeding line developed at the Univ. of Wisconsin, has short plants, pink flowers, round mottled seeds, and thin pod walls that lack parchment. NOF, a snow pea cultivar developed by Nunhems Seed Co., is early maturing, with a short plant, white flowers, small pods with thin walls, and round seeds with a black hilum. SD, released in 1985 by Gallatin Valley Seed Co., has white flowers, wrinkled seeds, and a snap type pod.

The stringy parents in the inheritance study included one snow pea and one snap pea. 'Oregon Sugarpod II' (OSP), a typical snow pea developed at Oregon State Univ. (OSU), has medium height, medium maturity, and dimpled seeds (Baggett, 1982). OSU 705 (705) is an OSU snap pea breeding line with wrinkled seeds.

Crosses were made in greenhouses using the standard emasculation technique. All possible crosses were made between the stringless and the stringy parents, and among the stringless parents. Reciprocal backcrosses were made between parents and $F_{1}$ progenies.

$\mathrm{F}_{2}$ and $\mathrm{F}_{3}$ seed were produced and the experiments were observed on the OSU Vegetable Research Farm. With the exceptions noted, seeds were planted with a belt planter $4 \mathrm{~cm}$ deep at $5-\mathrm{cm}$ intervals in rows $92 \mathrm{~cm}$ apart.

Genetic observations. $\mathrm{F}_{1}$ data and $\mathrm{F}_{2}$ seed were obtained from plants spaced $10 \mathrm{~cm}$ apart in the field. The following year, $\mathrm{F}_{2}$ populations were planted on two dates with three replications

Abbreviations: NOF, 'Nofila' snow pea; OSP, 'Oregon Sugarpod II' snow pea; OSU, Oregon State Univ.; SD, 'Sugar Daddy' snap pea. 
at each date. As there were relatively few backcross seeds, they were planted on a single date in two replications.

At edible maturity, presence or absence of strings was determined for all plants. In addition, pod type (snap or snow pea), plant height, and length and width of the first pod were recorded for all backcross plants and for 10 randomly selected stringypodded plants (stringy plants) and all stringless-podded plants (stringless plants) in each $\mathrm{F}_{2}$ plot in the first planting date. The following year, $F_{3}$ families derived from individual stringy $F_{2}$ plants were planted in a completely randomized design on two dates. Presence or absence of strings was determined for all plants, while pod type, plant height, and pod length and width were recorded for 10 randomly selected stringy plants and all stringless plants in each segregating family. Only presence or absence of strings was determined for nonsegregating families.

Observed ratios were tested for fit to single recessive gene and duplicate recessive gene hypotheses. $F_{1}$ and $F_{2}$ reciprocal cross data were determined by homogeneity test to be from the same population and were combined.

To test the relationship of stringlessness with plant height, pod length, and pod width, data on the measurements were sorted by presence vs. absence of string and pod type (when applicable) and combined over all generations within each cross. Differences between the mean of stringy and stringless individuals for plant height, pod length, and pod width were tested with Student's $t$ test, taking into account unequal numbers of observations (Sokal and Rohlf, 1981).

The relationship of smooth vs. wrinkled seed with stringlessness was determined in crosses between SD (stringless pod with wrinkled seeds) and OSP (stringy pod with smooth seeds). Before planting, $\approx 1400 \mathrm{~F}_{2}$ seeds were sorted into round and wrinkled lots that were planted and observed in separate adjacent plots.

\section{Results}

Inheritance of stringlessness. The stringless parents were consistently stringless when grown with progenies in the various field plantings, indicating that expression of stringlessness was not appreciably affected by environment. At least $16 \mathrm{~F}_{1}$ plants and 74 backcross $F_{1} \times$ stringy parent plants were grown for each cross. All were stringy, indicating that stringlessness is a completely recessive character. $F_{1}$ plants from crosses between different stringless parents were stringless, confirming that the three stringless parents carried the same factor(s) for stringlessness.

$\mathrm{F}_{2}$ segregation ratios (Table 1) ranged from 24 stringy : 1 stringless $(\mathrm{SD} \times \mathrm{OSP})$ to 65 stringy : 1 stringless $(\mathrm{L} 169 \times$ OSP $)$ and showed no obvious or consistent pattern. Deviation from a 3 stringy : 1 stringless ratio was significant $(P<0.001)$, with large $\chi^{2}$ values. When a duplicate recessive gene hypothesis was tested, $\chi^{2}$ values were much smaller; those from SD $\times$ OSP and both crosses with NOF as the stringless parent were smaller than the critical value for significance at $P=0.05$. Regardless of the ratio tested, all progenies included fewer stringless individuals than expected.

Populations of $\mathrm{F}_{3}$ families, which were obtained from stringy $\mathrm{F}_{2}$ plants, were tested against 2 segregating : 1 nonsegregating and 8 segregating : 7 nonsegregating ratios expected for one and two recessive gene hypotheses, respectively (Table 2). Based on the low frequency of stringless plants observed in the $F_{2}$ generation, $\mathrm{F}_{3}$ families that had fewer than the arbitrary number of 30 plants and had no stringless plants were discarded rather than counted as nonsegregating. Observed ratios in SD $\times 705$ and NOF $\times 705$ fit the expected 2 segregating: 1 nonsegregating ratio, whale the remaining four crosses had fewer segregating families than expected. When these populations were tested against the 8 segregating : 7 nonsegregating ratio, only L169 $\times \mathrm{OSP} \mathrm{F}_{3}$ deviated significantly, with fewer than expected segregating families.

Segregation ratios obtained in backcrosses between the $F_{1}$ and the stringless parent differed greatly, depending on whether the $F_{1}$ or the stringless parent was used as the male (Table 3). When the $F_{1}$ was the male parent, the number of stringless plants was much smaller than expected, comprising only $\approx 10 \%$ of the population rather than the $50 \%$ expected for a single recessive gene. Ratios for two of these backcrosses with the $F_{1}$ as male fit expected values for the duplicate recessive hypothesis, but none fit the ratio expected for a single gene. When the stringless parent was used as the male parent in the backcross, the percent stringless plants averaged $44 \%$ in the six crosses. Stringless plants outnumbered stringy plants in the two NOF crosses, but these were not available in the reciprocal backcrosses for comparison. All of the observed ratios for backcrosses with the $F_{1}$ as female (Table 3$)$, except for $(\mathrm{SD} \times 705) \times \mathrm{SD}$, fit the expected $1: 1$ at $P=0.05$ or 0.01 , and two of them fit the 3 stringy : 1 stringless ratio expected for duplicate recessive genes. The large difference in recovery of stringless plants in these reciprocal backcrosses suggests that when the heterozygous $F_{1}$ is the source of pollen, pollen carrying the stringless allele does not compete effectively with pollen carrying the stringy allele. When the homozygous stringless parent is used as the pollen parent in backcrosses, such competition does not exist.

Pod and plant size. There was an apparent pleiotropic association, in segregating populations, between the stringless character and reduced pod length, pod width, and plant height. In each cross, stringy pods were at least $22 \%$ longer than stringless pods in snow pea plants, and at least $14 \%$ longer in snap pod

Table 1. Segregation ratios of stringy $(+)$ : stringless $(-)$ podded pea plants in $F_{2}$ progenies tested against single and duplicate recessive gene hypotheses ${ }^{\mathrm{z}}$.

\begin{tabular}{|c|c|c|c|c|c|c|c|c|}
\hline \multirow[b]{3}{*}{ Cross } & & & \multicolumn{6}{|c|}{ Expected } \\
\hline & \multicolumn{2}{|c|}{ Observed } & \multicolumn{3}{|c|}{$3: 1$ ratio } & \multicolumn{3}{|c|}{$15: 1$ ratio } \\
\hline & + & - & + & - & $x^{2}$ & + & - & $x^{2}$ \\
\hline$\overline{\mathrm{SD} \times \mathrm{OSP}}$ & 431 & 18 & 337 & 112 & $105.1^{* *}$ & 421 & 28 & $3.8^{\mathrm{NS}}$ \\
\hline$S D \times 705$ & 474 & 17 & 368 & 123 & $121.9^{* *}$ & 460 & 31 & $6.7^{* *}$ \\
\hline L169 x OSP & 392 & 6 & 298 & 100 & $118.0^{* *}$ & 373 & 25 & $15.4^{* *}$ \\
\hline L169 x 705 & 380 & 6 & 290 & 96 & $112.3^{* *}$ & 362 & 24 & $14.4^{* *}$ \\
\hline NOF $\times$ OSP & 255 & 10 & 199 & 66 & $63.3^{* *}$ & 249 & 17 & $3.0^{\mathrm{NS}}$ \\
\hline NOF $\times 705$ & 160 & 4 & 123 & 41 & $44.5^{* *}$ & 154 & 10 & $3.8^{\mathrm{NS}}$ \\
\hline
\end{tabular}

${ }^{\mathrm{z}}$ Number of stringless plants in parents: SD 600/600, NOF 600/600, L169 600/600, OSP 0/600, 705 0/600. Nonsignificant or significantly different from expected values at $P=0.05$ and 0.01 , respectively. 


\begin{tabular}{|c|c|c|c|c|c|c|c|c|}
\hline \multirow[b]{3}{*}{$\mathrm{F}_{3}$ population } & & & \multicolumn{6}{|c|}{ Expected } \\
\hline & \multicolumn{2}{|c|}{ Observed } & \multicolumn{3}{|c|}{$2: 1$ ratio } & \multicolumn{3}{|c|}{$8: 7$ ratio } \\
\hline & Seg. & Nonseg. & Seg. & Nonseg. & $x^{2}$ & Seg. & Nonseg. & $x^{2}$ \\
\hline SD $\times$ OSP & 32 & 42 & 49 & 25 & $17.5^{* *}$ & 39 & 35 & $2.7^{\mathrm{NS}}$ \\
\hline$S D \times 705$ & 40 & 24 & 43 & 21 & $0.6^{\mathrm{NS}}$ & 34 & 30 & $2.3^{\mathrm{NS}}$ \\
\hline L169 $\times$ OSP & 30 & 62 & 61 & 31 & $46.8^{* *}$ & 49 & 43 & $15.8^{* *}$ \\
\hline L169 × 705 & 38 & 45 & 55 & 28 & $15.6^{* *}$ & 44 & 39 & $1.7^{\mathrm{NS}}$ \\
\hline NOF $\times$ OSP & 26 & 25 & 34 & 17 & $5.6^{*}$ & 27 & 24 & $0.1^{\mathrm{NS}}$ \\
\hline NOF $\times 705$ & 21 & 18 & 26 & 13 & $2.9^{\mathrm{NS}}$ & 21 & 18 & $0.0^{\mathrm{NS}}$ \\
\hline
\end{tabular}

${ }^{2} \mathrm{~F}_{3}$ families were obtained from stringy $\mathrm{F}_{2}$ plants only. No. of stringless plants in parents: SD 200/200, NOF 200/200, L169 200/200, OSP 0/200, 705 0/200.

$\mathrm{NS}, *, * *$ Nonsignificant or significantly different from expected values at $P=0.05$ and 0.01 , respectively.

Table 3. Ratios of stringy $(+)$ : stringless $(-)$ podded pea plants in backcrosses of stringless parent $x$ $\mathrm{F}_{1}$ and reciprocal tested against single- and duplicate-recessive gene hypotheses.

\begin{tabular}{|c|c|c|c|c|c|c|c|c|}
\hline \multirow[b]{3}{*}{ Backcross $^{2}$} & & & \multicolumn{6}{|c|}{ Expected } \\
\hline & \multicolumn{2}{|c|}{ Observed ${ }^{y}$} & \multicolumn{3}{|c|}{ 1:1 ratio } & \multicolumn{3}{|c|}{ 3:1 ratio } \\
\hline & + & - & + & - & $\chi^{2}$ & + & - & $x^{2}$ \\
\hline $\mathrm{SD} \times(\mathrm{SD} \times \mathrm{OSP})$ & 26 & 5 & 15.5 & 15.5 & $14.2^{* *}$ & 23 & 8 & $1.5^{\mathrm{NS}}$ \\
\hline$S D \times(S D \times 705)$ & 31 & 5 & 18.0 & 18.0 & $18.8^{* *}$ & 27 & 9 & $2.4^{\mathrm{NS}}$ \\
\hline L169 $\times($ L169 $\times$ OSP $)$ & 45 & 3 & 24.0 & 24.0 & $36.8^{* *}$ & 36 & 12 & $9.0^{* *}$ \\
\hline L169 x (L169 × 705) & - 42 & 4 & 23.0 & 23.0 & $31.4^{* * *}$ & 34 & 12 & $7.2^{*}$ \\
\hline$(S D \times$ OSP $) \times S D$ & 20 & 14 & 17.0 & 17.0 & $1.1^{\mathrm{NS}}$ & 26 & 8 & $5.9^{*}$ \\
\hline$(S D \times 705) \times S D$ & 27 & 11 & 19.0 & 19.0 & $6.7^{*}$ & 28 & 10 & $0.1^{\mathrm{NS}}$ \\
\hline$(\mathrm{L} 169 \times$ OSP $) \times \mathrm{L} 169$ & 32 & 19 & 25.5 & 25.5 & $3.3^{\mathrm{NS}}$ & 38 & 13 & $3.7^{\mathrm{NS}}$ \\
\hline
\end{tabular}

${ }^{2}$ Backcrosses NOF $\times F_{1}$ were not available.

yNumbers of stringless plants observed in parents were: SD 200/200, NOF 200/200, L169 200/200, OSP $0 / 200,7050 / 200$.

NS,*,**Nonsignificant or significantly different from expected values at $P=0.05$ and 0.01 , respectively.

Table 4. Average length and width of pods from stringy vs. stringless podded pea plants from all generations combined.

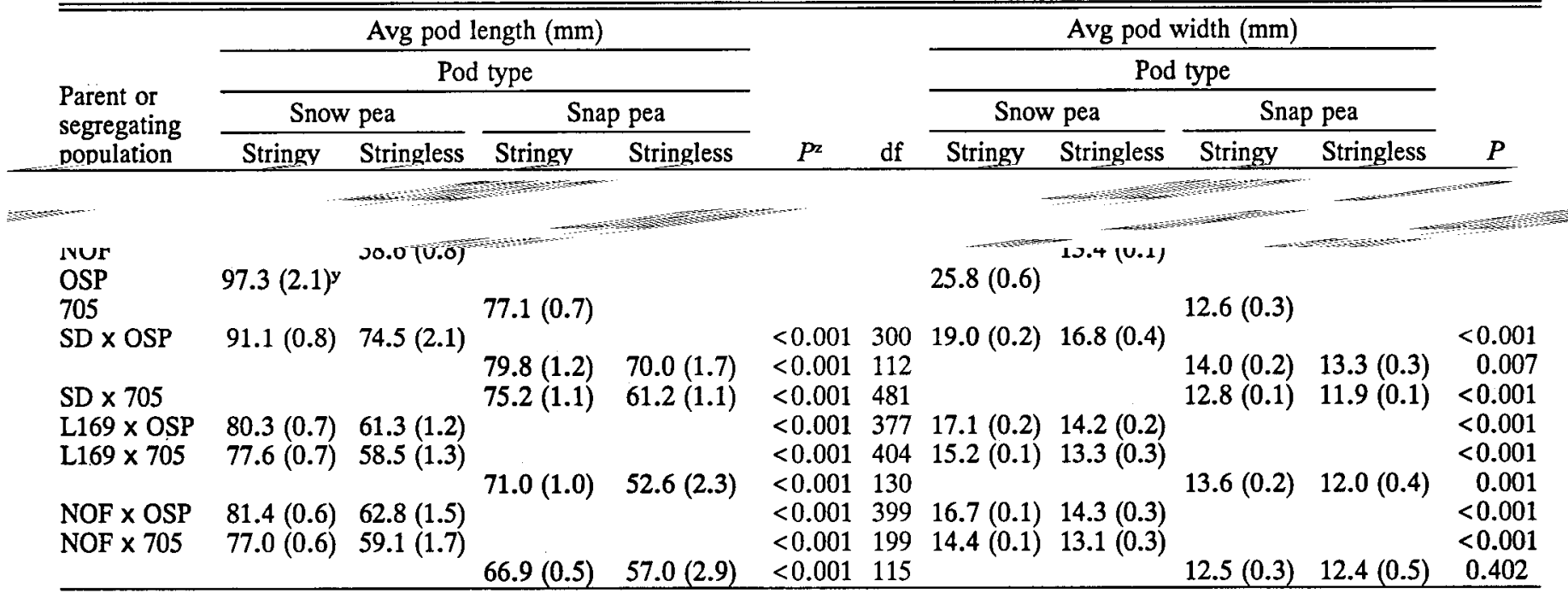

zProbability level, Student's $t$ test. Degrees of freedom are the same for length and width comparisons.

'SE shown in parentheses. 
plants. In each case, probabilities of $P<0.001$ were indicated by Student's $t$ test (Table 4).

Within each pod type in each cross, pods of stringless plants were narrower than pods of stringy plants (Table 4). Only in the cross NOF $\times 705$ was the difference between stringy and stringless individuals not significant $(P=0.402)$. In the other crosses, stringy snow pea pods were at least $10 \%$ wider than stringless snow pea pods, and in the snap plants, stringy pods were at least $5 \%$ wider than stringless pods.

Plants were not separated by pod type in the analysis of plant height differences. In each cross, stringless plants were significantly $(16 \%$ to $20 \%)$ shorter than the stringy plants $(P<0.001$, Table 5).

Seed type. Independence of segregation for stringless pod and wrinkled seed was tested by a contingency table $\chi^{2}$ test (Table 6 ). The frequency of stringless plants segregating from smooth seeds was $1 / 29$, while the frequency of stringless plants from wrinkled seeds was $1 / 82$. The $\chi^{2}$ value was significant at $P=$ 0.05 , suggesting a negative association between wrinkled seeds and stringless pods.

\section{Discussion}

The stringless pod character was obtained by treatment of peas with ethylenimine (Wellensiek, 1971), a biological alkylating agent (Dermer and Ham, 1969). Since alkylating agents usually act by inducing point mutations rather than chromosomal aberrations, our original working hypothesis was that stringlessness originated as a single gene mutation. While the stringy condition of the $F_{1}$ and segregation ratios of succeeding generations clearly indicate that stringlessness is recessive, attempts to confirm that one locus is involved have been confused by variable results and by a generally inadequate number of

Table 5. Average plant height of stringy- vs. stringless-podded plants from all generations with snow peas and snap peas not separated.

\begin{tabular}{lllll}
\hline \hline $\begin{array}{l}\text { Parent or } \\
\text { segregating } \\
\text { population }\end{array}$ & \multicolumn{2}{c}{ Avg ht $(\mathrm{cm})$} & & \\
\cline { 2 - 3 } SD & Stringy & Stringless & $P^{z}$ & df \\
L169 & & $66.5(2.8)$ & & \\
NOF & & $52.7(3.3)$ & & \\
OSP & & $44.4(4.4)$ & & \\
705 & $78.8(2.4)$ & & & \\
SD $\times$ OSP & $74.4(2.2)$ & & & \\
SD $\times 705$ & $79.5(0.7)$ & $66.5(2.0)$ & $<0.001$ & 414 \\
L169 x OSP & $80.9(0.7)$ & $60.8(1.3)$ & $<0.001$ & 481 \\
L169 $\times 705$ & $75.2(0.7)$ & $55.6(1.6)$ & $<0.001$ & 377 \\
NOF $\times$ OSP & $76.9(0.8)$ & $57.6(1.4)$ & $<0.001$ & 404 \\
NOF x 705 & $66.2(0.8)$ & $49.5(1.5)$ & $<0.001$ & 399 \\
\hline
\end{tabular}

zProbability level, Student's $t$ test.

${ }^{y_{S E}}$ shown in parentheses.

Table 6. Chi-square contingency table test for independence between seed type and pod stringiness in $F_{2}$ pea plants from the cross SD $x$ OSP.

\begin{tabular}{|c|c|c|c|c|c|c|c|}
\hline \multirow[b]{2}{*}{ Seed type } & \multicolumn{3}{|c|}{ Plants observed (no.) } & \multicolumn{2}{|c|}{$\begin{array}{l}\text { Plants expected } \\
\text { (no.) }\end{array}$} & \multirow[b]{2}{*}{ Total } & \multirow[b]{2}{*}{$x^{2}$} \\
\hline & Stringy & Stringless & Ratio & Stringy & Stringless & & \\
\hline Smooth & 1030 & 36 & $29: 1$ & 1036 & 30 & 1066 & \\
\hline Wrinkled & 328 & 4 & $82: 1$ & 322 & 10 & 332 & \\
\hline Total & 1358 & 40 & $34: 1$ & 1358 & 40 & 1398 & $4.3^{*}$ \\
\hline
\end{tabular}

*Significantly different from expected values at $P=0.05$. stringless plants to support a single recessive gene hypothesis. In view of the small number of stringless plants in the $F_{2}$, the obvious alternative was to test against ratios expected for a duplicate recessive gene, and this resulted in much smaller $\chi^{2}$ values, some of which indicated an acceptable fit. Tests of $\mathrm{F}_{3}$ families from stringless $\mathrm{F}_{2}$ plants, where it was only necessary to distinguish between segregating and homozygous stringy families, produced smaller $\chi^{2}$ values that were nonsignificant or nearly so for a single-gene ratio in three crosses. The $\mathrm{F}_{3}$ results tended to support the single recessive gene hypothesis.

Backcross tests provide the best support for a single-gene hypothesis and lead to a plausible explanation for observed deficiencies of stringless plants. While backcrosses made with the $F_{1}$ as the pollen parent were deficient in stringless plants (though less so than were the $\mathrm{F}_{2}$ progenies), backcrosses made with stringless parents as pollen source gave close fits to the expected 1 stringy : 1 stringless ratio.

The low recovery of stringless plants might be explained by stringless seedlings that are not as robust or vigorous and may not germinate or survive as well as stringy seedlings. Stringless purelines, i.e., the parent cultivars, may germinate poorly, compared with stringy cultivars, under adverse conditions but did not show noticeably reduced percent germination under the conditions of our tests. Second, cytological irregularities related to the origin of the mutant by chemical induction could cause aberrant ratios, but examination of meiotic configurations during the study failed to disclose such irregularities. Third, unfavorably low temperatures could prevent full expression of stringlessness. However, stringless parents planted as controls with segregating populations were always stringless in this study. A more promising hypothesis, however, relates to the competitive ability of pollen carrying the stringless factor(s). The observation that backcrosses using the $F_{1}$ as male parent produced fewer stringless plants than the reciprocals suggests that stringless pollen sometimes fails to effect fertilization in competition with stringy pollen. Experimental evidence supporting this hypothesis was obtained by pollen germination studies (McGee and Baggett, 1992).

The maximum recovery of stringless segregates we were able to obtain, which was in the backcross $F_{1} \times$ stringless parent, was adequate to support the hypothesis that stringlessness is controlled by a monogenic recessive gene. Because of this and because of the nature of the origin of the character by chemical mutagenesis, we conclude that stringlessness is controlled by a single recessive gene for which we propose the symbol sin-2. Further study would be required to determine if $\sin -2$ is allelic to previously named genes such as $\sin$. We tested accessions purported to carry $\sin$ but were unable to detect any reduction of strings. Since the original sin germplasm may be lost, tests for allelism may not be possible.

We have observed some variation in degree of stringlessness. While microclimatic effects may explain some of these variations, fixed differences in degree of stringlessness observed among pure lines indicate that there are modifying genes affecting expression of this trait, thus making it more difficult for a breeder to produce stringless lines of acceptable quality. Equally important are the associations demonstrated in this study between stringlessness and reduced pod and plant size. These reductions reflect the observed (but not measured in this study) general reduction in productivity of stringless pea plants, which usually includes a reduction in the number of nodes bearing two pods. The reduction of pod size and overall productivity appears to be a pleiotropic effect of the stringless gene. It is a significant 
hindrance to the breeding of stringless cultivars with yields similar to those of normal cultivars.

Data were obtained on the association of stringlessness and smooth vs. wrinkled seed, controlled by the $r$ locus (White, 1917), because we had noted a tendency for a higher than expected number of smooth-seeded stringless segregates. The number of stringless wrinkled-seeded plants was about one-half the expected number as determined by contingency table test, and the $\chi^{2}$ value was significant at $P=0.05$. This result suggests that the stringless gene in combination with the wrinkled seed gene $r$ may result in seeds or seedlings with less potential to produce a viable seedling.

\section{Literature Cited}

Baggett, J.R. 1982. 'Oregon Sugarpod II' edible pod pea. HortScience 17:93-94.
Dermer, O.C. and G.E. Ham. 1969. Ethylenimine and other aziridines. Academic, New York. p. 394-399.

Lamprecht, H. 1938. Uber Hülseneigenschaften bei Pisum, ihre Vererbung und ihr Züchterischer Wert. Der Züchter 10:150-157.

McGee, R.J. and J.R. Baggett. 1992. Differential growth rate of pollen tubes from normal and stringless pea cultivars. HortScience 27:833834.

Sokal, R.R. and F.J. Rohlf. 1981. Biometry. 2nd ed. Freeman, San Francisco. p. 242-245.

Thorndyke, J. 1983. The making of the 'Sugar Snap' pea. Horticulture 61:14-15.

Wehner, T.C. and E.T. Gritton. 1981. Effect of the $n$ gene on pea pod characteristics. J. Amer. Soc. Hort. Sci. 106:181-183.

Wellensiek, S.J. 1925. Pisum crosses I. Genetics 7:1-64.

Wellensiek, S.J. 1971. Lamprecht's gene $\sin$ for stringless. Pisum Newsletter 3:48.

White, O.E. 1917. Studies of inheritance in Pisum. II. Present state of knowledge. Proc. Amer. Philosophical Soc. 56:487-588. 